\title{
Positive bromide partition test in the absence of tuberculous meningitis
}

\author{
JR WEINBERG, SP COPPACK \\ From the Departments of Medicine and Neurology, Brook General Hospital, London, UK
}

SUMMARY Five cases of lymphocytic meningitis are described where a Bromide Partition Test was performed and proved positive at levels usually considered consistent with tuberculous meningitis. Three of these cases were ultimately shown to have herpes simplex viral encephalitis, one had Listeria monocytogenes in the CSF and the fifth patient recovered without treatment and was thought to have had a viral encephalitis. The Bromide Partition Test may not be as good a discriminant as has previously been suggested in differentiating between tuberculous and viral meningitis, especially when performed in a population at low risk of getting tuberculous meningitis.

The early treatment of tuberculous meningitis is prognostically important. Patients frequently need to be treated before the results of their CSF culture is available and on the basis of their clinical appearance and the CSF microscopy, sugar and protein. It has been suggested that the Bromide Partition Test is a useful discriminant between viral and tuberculous meningitis. ${ }^{3}$ The normal plasma bromide is 2.5-3.5 times that of CSF; several studies have reported that a Serum/CSF bromide ratio below $1 \cdot 6,,^{23}$ or $1 \cdot 9,,^{4}$ is strongly suggestive of tuberculous meningitis. This ratio can be estimated by either a chemical $^{6}$ or radio isotope ${ }^{7}$ method, following the oral or intravenous administration of a suitable bromide preparation. We describe five consecutive cases of lymphocytic meningitis who had bromide ratios determined by a chemical method; none of these cases had a final diagnosis of tuberculous meningitis: however, the Bromide Partition Test in each case was strongly suggestive of tuberculous meningitis. We discuss why our experience is different from that previously described.

\section{Case reports}

(See table for CSF findings)

Case 1

A 47-year-old previously fit housewife developed abdominal pain, headache and fever one week before admission.

Address for reprint requests: Dr JR Weinberg, Lister Unit, Northwick Park Hospital, Watford Road, Harrow, Middlesex, HA1 3UJ, UK.

Received 17 July 1984.

Accepted 21 August 1984
She then became confused, aggressive and finally dysphasic. On examination she was pyrexial with an absent gag reflex, neck stiffness, dysphasia, a spastic quadraparesis more marked on the right, and extensor plantar responses. EEG and brain CT scan supported a diagnosis of herpes simplex encephalitis; this was treated with acyclovir. Complement fixing antibodies to herpes simplex virus rose 16 -fold in the CSF.

\section{Case 2}

A previously fit 38-year-old seaman suffered 5 weeksō intermittent malaise and fever. Four days prior to admis-? sion he collapsed at work. He then became progressively dysphasic with fever, fits, neck stiffness and a mild right sided spastic hemiparesis. EEG and brain CT scan suggested the diagnosis of herpes simplex encephalitis, and the patient was treated with acyclovir. Complement fixing antibodies to herpes simplex virus rose 8-fold in both CSF and serum.

\section{Case 3}

A 56-year-old teacher taking steroids for asthma developed a neck ache 6 days before admission. She subsequently developed headache, vomiting, lumbar back ache and fluctuating drowsiness. On admission she was pyrexial, drowsy and disorientated. She had meningism, nystagmus, early papilloedema, convergent strabismus, loss of the right corneal reflex, a right palatal palsy, deviation of the tongue to the right, a right-sided facial weakness, dysarthria and a right spastic hemiparesis with bilateral extensor plantar responses. She required tracheostomy and was treated with broad spectrum antibiotics. Anti-tuberculous chemotherapy was instituted. Ultimately Listeria monocytogenes was cultured from the CSF.

Case 4

A previously fit 34-year-old woman developed malaise and 
Table CSF results

\begin{tabular}{|c|c|c|c|c|c|c|c|c|}
\hline Case & $\begin{array}{l}\text { Pressure } \\
\mathrm{mm} \text { CSF }\end{array}$ & Lymphocytes $P$ & $\begin{array}{l}\text { Polymorphs } \\
\mid \mu l\end{array}$ & $\begin{array}{l}\text { Monocytes } \\
/ \mu l\end{array}$ & $\begin{array}{l}\text { Red cells } \\
/ \mu l\end{array}$ & $\begin{array}{l}\text { Protein } \\
\mathrm{g} / \mathrm{l}\end{array}$ & $\begin{array}{l}\text { Glucose } \\
\text { Mol/l }\end{array}$ & $\begin{array}{l}\text { Bromide } \\
\text { Partition Test } \\
\text { Serum/CSF }\end{array}$ \\
\hline $\begin{array}{l}1 \\
2 \\
3 \\
4 \mathrm{i} \\
\mathrm{ii} \\
5 \mathrm{i} \\
\quad \mathrm{ii} \\
\mathrm{iii}\end{array}$ & $\begin{array}{l}24 \\
15 \\
26\end{array}$ & $\begin{array}{r}35 \\
183 \\
245 \\
250 \\
260 \\
3 \\
5 \\
2\end{array}$ & $\begin{array}{r}0 \\
4 \\
256 \\
20 \\
0 \\
0 \\
1 \\
0\end{array}$ & $\begin{array}{l}2 \\
0 \\
0 \\
0 \\
0 \\
0 \\
0 \\
0\end{array}$ & $\begin{array}{r}2 \\
45 \\
0 \\
7 \\
0 \\
0 \\
9 \\
0\end{array}$ & $\begin{array}{l}0.820 \\
0.815 \\
0.800 \\
0.660 \\
1.100 \\
0.090 \\
0.120 \\
0.825\end{array}$ & $\begin{array}{l}3 \cdot 1(5 \cdot 0) \\
4 \cdot 0 \\
5 \cdot 4(11 \cdot 4) \\
2 \cdot 8(4 \cdot 3) \\
2 \cdot 9(4 \cdot 8) \\
3 \cdot 4 \\
2 \cdot 6\end{array}$ & $\begin{array}{l}0.63 \\
1.15 \\
1.1 \\
1.5\end{array}$ \\
\hline
\end{tabular}

Figures in brackets show blood glucose

lightheadedness. Two days later she became aphasic. She was pyrexial with a stiff neck, positive Kernig's sign, bilateral ankle clonus, brisk reflexes and extensor plantar responses. She had a severe expressive dysphasia. Brain CT scan showed "patchy low density in the left temporal region, possibly elsewhere, but no midline shift. Enhancement around brain stem. Possible encephalitis. TB could not be excluded". Anti-tuberculous therapy was started after the Bromide Partition Test was performed. EEG was suggestive of of herpes simplex encephalitis, and acyclovir was commenced. Herpes complement fixing antibodies to herpes simplex virus rose 8 -fold in serum and 16 -fold in CSF.

Case 5

A previously fit 13-year-old boy presented after a month long illness. This began with a sore throat and erythematous rash; he then developed a persisting pyrexia which did not respond to antibiotics. Full blood count and ESR were normal. Four days before admission he developed night sweats, neck ache, became drowsy and was incontinent of urine. He was drowsy but orientated. The neck was stiff and there was a pyramidal weakness of the legs with extensor plantar responses. He had bilateral papilloedema. Brain CT scan was normal. The child deteriorated and burr holes were performed to exclude sub-dural pus. The brain appeared normal. Post operatively the pyramidal weakness became worse. A myelogram was performed which was normal. An EEG post operatively was thought to be consistent with an encephalitis. A Bromide Partition Test was performed one week after the myelogram. The child made a good recovery over three weeks on no treatment, and had no abnormal signs three months later. CSF and serum viral studies were unhelpful.

\section{Discussion}

The mechanism by which the serum/CSF bromide ratio is perturbed in tuberculous meningitis is unknown. If the test is specific to tuberculous meningitis the mechanism must be exclusive to that disease. It has been suggested that meningeal hypersensitivity to tuberculin may be responsible; intra-thecal tuberculin certainly disrupts the bloodbrain barrier. ${ }^{8}$ Earlier studies using the Bromide Partition Test have reported a false positive rate of about $10 \%$ where a critical ratio of 1.9 or 1.6 was used. In a small study Mandal et $a l^{2}$ reported no false positives using the radio-labelled bromide test; however, this has had a similar false positive rate to the chemical version of the test in other larger studies. ${ }^{34}$.

We are not sure of the causes of the false positive results in our patients. Case 5 had had a recent myelogram and it seems probable that the iodine cross-reacted in the chemical assay. The literature to date mainly describes the use of the Bromide Partition Test in high risk populations. The proportion of false positive results is likely to rise as the prevalence of the disease falls; it may be that the Bromide Partition Test is not as useful in our population where the risk of tuberculous meningitis is low when compared to the Indian and South African populations previously studied, or the patients of an infectious disease centre.

A further major problem with the Bromide Partition Test is the delay in treatment which may occur whilst waiting for the isotope to equilibrate. Hopefully an alternative isotope, which is a good discriminant for tuberculous meningitis and which equilibrates rapidly across the blood-brain barrier can be found. Meanwhile we suggest caution in the interpretation of the Bromide Partition Test and that a positive result should not halt the consideration of other diagnoses, especially if there is any clinical doubt.

We thank Dr J Condon, Dr W Michael and Mr M Sharr for allowing us to report patients who were under their care.

\section{References}

' Parsons M. Diagnoses not to be missed. Tuberculous meningitis. Br J Hosp Med 1982;27:682-4.

2 Mandal BK, Evans DIK, Ironside AG, Pullen BR. Radioactive Bromide Partition test in differential diagnosis of tuberculous meningitis. $\mathrm{Br}$ Med $J$ 1972;4:413-5. 
${ }^{3}$ Wiggelinkhuizen $\mathbf{J}$, Mann $\mathbf{M}$. The radioactive bromide partition test in the diagnosis of tuberculous meningitis in children. $J$ Pediatr 1980;97:843-7.

${ }^{4} \mathrm{Da}$ Costa H, Borker A, Loken M. Distribution of orally administered Bromine-82 in tuberculous meningitis: concise communication. J Nucl Med 1977;18:123-4.

s Shepstone BJ. Tuberculous Meningitis. Br J Hosp Med 1982;28:446.

6 Varley H, Gowenlock AH, Bell M. Practical Clinical
Biochemistry, Volume 2. Hormones, Vitamins and Poisons. 5th Ed. London: Heinemann 1976: 310.

${ }^{7}$ Crook A, Duncan H, Gutteridge B, Pallis C. Use of ${ }^{82} \mathrm{Br}$ in differential diagnosis of lymphocytic meningitis. $\mathrm{Br}$ Med J 1960;1:704-6.

8 Taylor LM, Smith HV, Hunter G. The blood-CSF barrier to bromide in diagnosis of tuberculous meningitis. Lancet 1954;1:700-2. 